DOI 10.22363/2312-8313-2019-6-1-12-17

Research article

\title{
Political reforms in Jordan following the events of the Arab Spring
}

\author{
Mazen Hawamdeh, Ahmad Al-Qteishat \\ Peoples’ Friendship University of Russia (RUDN University)
}

Following the events of the Arab Spring and the popular protests that broke out in some countries in the Arab world in 2011, including Jordan, extended political reforms were carried out in Jordan, including major constitutional amendments and developments in political life, political parties and civil society institutions.

The study aims to identify the reality of the political reform process in Jordan that took place after the events of the Arab Spring. The importance of the study stems from the depth of the effects of the variables of this period on Jordan and its reform programs and its transformations towards democracy.

The study aims to achieve the following objectives: To identify the nature of the factors and reasons that contributed to the outbreak of the current Arab revolutions, and identifying the reality of the process of political reform in Jordan before the events of the Arab Spring, and to study and analyze the political reforms in Jordan after the events of the Arab Spring.

Keywords: Arab Spring, Jordan, Political Reform, Constitution, Executive Authority

The concept of political reform refers to the idea of political modernization, the building of democracy, the disciplined change in the level of political evolution, and the institutional and cultural developments, the development of the constitutional organization of the state authorities, the achievement of accountability and the focus on popular participation at all levels, the mobilization of the state apparatus and the guarantee of general rights and freedom for all citizens. And empower them to have their rights and enjoyment of their freedoms guaranteed by the Constitution and the law.

Since its inception, the State of Jordan has witnessed a number of stages that have expressed the evolution of political life in keeping with the internal, regional and international circumstances. In light of the reversals of Arab political and economic situations and the deteriorations in public freedoms and human rights in the Arab region, these situations contributed to the emergence of Arab protests and

(C) Hawamdeh M., Al-Qteishat A., 2019

This work is licensed under a Creative Commons Attribution 4.0 International License https://creativecommons.org/licenses/by/4.0/ 
revolutions that began in Tunis and moved to many Arab countries as an expression of their rejection of these conditions and the desire to reach a new phase of reform and development [1].

The protests in Jordan, which sprung up throughout Jordan in 2011, have led to a wave of demonstrations and protest rallies triggered by the wave of Arab protests that erupted in the Arab world. The main reasons for these protests were deteriorating economic conditions, high prices, widespread unemployment and widespread corruption, Administrative and financial.

The most important characteristic of the popular movement in Jordan is that it began from the time point before the eruption of Arab revolutions in Tunisia and Egypt. It came first in protest against the parliamentary elections that took place at the beginning of November 2010, and on the various governmental measures before and after that date. And has intensified with the granting of parliamentary confidence almost absolute and unprecedented to the government of Samir Rifai, which has not received popular acceptance from the citizens since its formation [2].

Labor mobility was the largest type of mobility and was associated with labor demands, often concentrated on wage increases. There were also so-called temporary committees (such as the Teachers Union Committee which reached its goal of formally establishing the teachers' union), and then political parties and student movements. During the first three months of 2011, protests and demonstrations multiplied more than eight times, but the pace of protests began to back down after the announcement of the National Dialogue Committee and the Royal Commission to amend the Constitution in April 2011, where some opposition parties decided to stop protests and demonstrations pending results these two committees.

The popular mobility in Jordan covered all regions in varying proportions and was comprehensive nationwide. However, the large number of events, protests and demonstrations in the capital region are observed in view of the largest population and the most influential political vitality. Also Deprivation the unity of living problems suffered by the majority of citizens there.

The period from April 2011 can be seen as an exceptional period in the lives of the peoples of a number of countries in the Arab region, which witnessed the outbreak of the Arab Spring revolutions in Tunisia, Egypt, Libya, Yemen and Syria, which formed a new political stage in those countries, governments were also put in front of new responsibilities based on the principle of negotiation with their people in order to reach national reconciliation, after old policies failed to carry out political and economic reforms.

In 27/4/2011, King Abdullah the second formed the Royal Committee for the Review of the Constitution. This initiative was also noted by many opposition parties and popular movements in response to the demands of the political and popular forces in the country. Especially when the king found that the gap between the political elites and the general society with its various components has begun to widen and increased levels of contradiction and the lack of trust between the parties, The King asked the Committee to adopt the outputs of the National Dialogue Committee regarding the required constitutional amendments with regard to electoral laws and parties [3]. 
The proposed constitutional amendments, which were subsequently reviewed by the Legal Committee of the House of Representatives, focused on the following points: the establishment of a Constitutional Court to examine the constitutionality of laws, And the formation of an independent commissions overseeing the parliamentary elections, and reducing the age of the candidate for membership of the House of Representatives from 30 years to 25 years, The trial of ministers in relation to the affairs of their ministries before the regular judiciary rather than the special courts, and the independence of the Judicial Council in matters relating to the regular courts.

The Anti-Corruption Commission work continued, and has been established under the Anti-Corruption Commission Law No. (62) For the year 2006 and its amendments, has continued. Article 4 of the Anti-Corruption Commission Law states that the Commission aims at combating corruption to: To establish effective policies in coordination with the relevant authorities to combat and prevent corruption and to expose corruption in all its forms, including financial and administrative corruption, and to provide the principles of equality, equality of opportunity and justice, and to cooperate in the submission and application of international legal assistance, Submission through official channels.

In 2014, the Law of Illegal Graft No (21) of 2014 was issued as a type of financial control. The law states that a department called the Financial Disclosure Department is established in the Ministry of Justice. The National Anti-Corruption Strategy (2013-2017) was designed to raise the level of awareness and education on the phenomenon of corruption and efforts to combat it, strengthen the capacity of the Anti-Corruption Commission, promote corruption prevention and activate community participation in anti-corruption activities and promote integrity, Strengthening international cooperation in combating corruption and developing national legislation in line with international standards and requirements for combating corruption.[4]

The Anti-Corruption Commission is considered to be the most important concern of a wide range of Jordanian citizens, as it has caused great damage to the national economy. The former parliament has contributed to open files of corruption and form commissions of inquiry.

The effect of the constitutional amendments in the Arab spring stage on political life in Jordan:

In this study, the impact of constitutional amendments on political life in Jordan will be taken into account in terms of the impact of constitutional amendments on the three branches of government (legislative, executive, judicial).

These constitutional amendments have had an impact on the political life of Jordan in terms of the impact of the constitutional amendments on the development of new political institutions in the political system. The constitutional amendments of 1952 and its amendments in the Arab spring stage have directly influenced the legislative authority, Where the constitutional amendments worked to immunize the House of Representatives of the solution by the executive authority, by considering that if the dissolution of the House of Representatives for a reason may not be dissolved the new Council for the same reason. [5]

The constitutional amendments stressed the need for the presence of the House of Representatives in the political life in Jordan, since under the provisions 
of the Constitution cannot remove the government of the House of Representatives from the political arena for more than four months, were elections must be held within four months of the expiry of the term of the Council. The role of the legislative authority was emphasized by increasing the duration of the regular session of the House of Representatives from four months to six months [6].

The constitutional amendments have directly affected the executive branch by forcing the government formed to proceed in a statement to gain the confidence of the house parliament which is represented by the people. The constitutional amendments emphasized the principle of the independence of the judiciary and the strengthening of its role in monitoring and accounting the executive authority by stipulating the trial of ministers for the crimes attributed to them from performing their duties before the competent courts in the capital, in accordance with the provisions of the law.

\section{Conclusion}

This study sought to prove that there is a direct relationship between political reform in Jordan after the events of the Arab Spring and the repercussions of the Arab Spring on Jordan, In other words, the response of the regime and the Jordanian government to the calls for change in some articles of the Constitution and the main laws and regulations have mitigated the negative effects on political stability in Jordan.

That the response of the Jordanian state to the demands of the popular political movement represented by the formation of a committee for national dialogue, and the introduction of a new law for political parties, and the formation of a Royal Committee to review the Constitution, And the adoption of the establishment of a union of teachers after the abstention for a long period of time, and strengthen the fight against corruption and the submission of officials to the judiciary, and the adoption of the law of the Independent Electoral Commission, and the law of political parties, The Constitutional Court laws Act and the Elections Law, all had a positive impact on the calm of the Jordanian street and the alleviation of the negative effects on political stability in Jordan.

The study recommends working on establishing a state of citizenship, rule of law and equal opportunity, expanding the area of political participation in decisionmaking and the direction towards good governance, Strengthening the principle of integrity, combating corruption, human rights, accountability and monitoring, and enhancing Jordanian society's confidence in governments and their institutions by asserting the independence and separation of powers and initiating a national dialogue for all the forces of society to achieve national interests.

\section{REFERENCES}

[1] Omar Yasseen Khudierat. Political Reforms in Jordan Following the Arab Spring revolts, 2018, p. 7-8. URL: https://www.researchgate.net/publication/323737966_alaslahat_alsyasyt_ fy_alardn_bd_ahdath_alrby_alrby (accessed: 17.03.2019). 
[2] Hassan A. BARARI, The Arab Spring: The Case of Jordan, Ortadoğu Etütleri, Volume 3, No 2, January 2012, p. 47. URL: https://www.orsam.org.tr/d_hbanaliz/2hassane.pdf (accessed: 17.03.2019).

[3] Saleh Abdul Razzaq Al Khawaldeh, Arab Spring effect on political reform in Jordan (2011-2014), 2018, p. 12. URL: https://www.researchgate.net/publication/327883815_ athr_alhrak_alshby_alrby_ly_alaslah_alsyasy_fy_alardn_2011-2014(accessed:17.03.2019).

[4] Saleh Abdul Razzaq Al Khawaldeh, The impact of the constitutional amendments in the Arab Spring stage on the political life in Jordan, 2017, p. 24. URL: https://www. researchgate.net/publication/327884577_athr_altdylat_aldstwryt_fy_mrhlt_alrby_ alrby_ly_alhyat_alsyasyt_fy_alardn/link/5bab59fd45851574f7e $681 \mathrm{f} 6 /$ /download (accessed: 17.03.2019).

[5] Mohammed Al - Arasan, Constitutional Amendments in Jordan: An Update for Reform or a Reversal of Reform?,2016.URL: https://arabi21.com/story/903432/\%D8 \%A7 \%D9 \%84 \%D8 \%AA \%D8 \%B9 \%D8 \%AF \%D9 \%8A \%D9 \%84 \%D8 \%A7 \%D8 \%AA- \%D8 \%A7 \%D9 \%84 \%D8 \%AF \%D8 \%B3 \%D8 \%AA \%D9 \%88 \%D8 \%B1 \%D9 \%8A \%D8 \%A9- \%D8 \%A8 \%D8 \%A7 \%D9 \%84 \%D8 \%A3 \%D8 \%B1 \%D8 \%AF \%D9 \%86- \%D8 \%A7 \%D8 \%B3 \%D8 \%AA \%D9 \%83 \%D9 \%85 \%D8 \%A7 \%D9 \%84- \%D9 \%84 \%D9 \%84 \%D8 \%A5 \%D8 \%B5 \%D9 \%84 \%D8 \%A7 \%D8 \%AD- \%D8 \%A3 \%D9 \%85- \%D8 \%AA \%D8 \%B1 \%D8 \%A7 \%D8 \%AC \%D8 \%B9\%D8 \%B9 \%D9 \%86 \%D9 \%87 (accessed: 17.03.2019).

[6] Mohammed Torki Bani Salameh, Political Reform in Jordan: Reality and Aspirations, February 2017, p. 56. URL: https://www.researchgate.net/publication/323401967_ Political_Reform_in_Jordan_Reality_and_Aspirations (accessed: 17.03.2019).

\title{
Information about the authors:
}

Mazen Hussien Faleh Hawamdeh - postgraduate Student of the Department of Comparative Politics, Peoples' Friendship University of Russia (RUDN University) (Russian Federation) (ORCID ID: 0000-0003-4463-2766) (e-mail: mazen_1616@yahoo.com)

Ahmad Saher Ahmad Al-Qteishat - postgraduate Student of the Department of Comparative Politics, Peoples' Friendship University of Russia (RUDN University) (Russian Federation) (ORCID ID: 0000-0003-3393-2210) (e-mail: ahmad_qteishat@hotmail.com)

Научная статья

\section{Политическая реформа в Иордании после событий Арабской весны}

\author{
М. Хавамдех, А. Аль Ктеишат
}

Российский университет дружбы народов

После событий Арабской весны и народных протестов, вспыхнувших в некоторых странах арабского мира в 2011 году, включая Иорданию, в Иордании были проведены расширенные политические реформы, в том числе крупные конституционные поправки и изменения в политической жизни, политических партиях и институтах гражданского общества. 
Целью исследования является выявление реальности процесса политических реформ в Иордании, который произошел после событий Арабской весны. Важность исследования связана с глубиной воздействия переменных этого периода на Иорданию и ее программы реформ и ее преобразования в сторону демократии.

Исследование направлено на достижение следующих целей: выявление характера факторов и причин, способствовавших началу нынешних арабских революций, и выявление реальности процесса политических реформ в Иордании до событий арабской весны, а также изучение и анализ политических реформ в Иордании после событий арабской весны.

Ключевые слова: Арабская весна, Иордания, политическая реформа, конституция, исполнительная власть

\section{Сведения об авторах:}

Хавамдех Мазен Хуссен Фалах - аспирант кафедры сравнительной политологии Российского университета дружбы народов (ORCID ID: 0000-0003-2695-5879) (e-mail: mazen_1616@yahoo.com).

Аль Ктеишат Ахмад Сахер Ахмад - аспирант кафедры сравнительной политологии Российского университета дружбы народов (ORCID ID: 0000-0002-3650-5460) (e-mail: ahmad_qteishat@hotmail.com). 